\title{
SUCCESSFUL COMMUNITY ENGAGEMENT AND IMPLEMENTATION OF A CONSERVATION PLAN IN THE SOLOMON ISLANDS: A LOCAL PERSPECTIVE
}

\author{
Jimmy Kereseka ${ }^{1 *}$ \\ *Corresponding author: jkereseka@tnc.org \\ ${ }^{1}$ Environment Officer, Lauru Land Conference of Tribal Community (LLCTC), Taro, Choiseul \\ Province, Solomon Islands
}

\begin{abstract}
The indigenous people and clans of Choiseul Province, or Lauru as it is known locally, retain strong customary ownership over their lands and seas, and maintain many customs relating to the use of their natural resources. The rural population of Lauru also has a strong collective voice through the Lauru Land Conference of Tribal Community (LLCTC). The activities of the LLCTC Environmental Office resulted in the establishment of eight Locally Managed Marine Areas (LMMAs) by 2008, and word of mouth on the value of these LMMAs generated numerous community requests to LLCTC for assistance in establishing additional protected areas. In 2009 a stakeholder-driven conservation plan for the whole of Lauru was developed, which led to a political commitment from the LLCTC and the government to establish a provincial-wide Lauru Protected Area Network, the first such commitment in Melanesia. By 2012, 15 LMMAs and several terrestrial community conserved areas had been established. This paper outlines the process of community engagement that the LLCTC Environmental office uses when establishing protected areas and some of the common misunderstandings that frequently need to be addressed. The paper also outlines how the stakeholder-driven implementation process is informed by the Choiseul Ridges to Reefs Conservation Plan that was developed using the best available scientific and local knowledge.
\end{abstract}

KEYWORDS: customary owners, indigenous people, Locally Managed Marine Areas, Choiseul Province, Solomon Islands, stakeholder-driven conservation plan

\section{INTRODUCTION}

Choiseul Province, or Lauru as it is known locally, is one of the nine provinces of Solomon Islands (Figure 1). It lies between the island of Bougainville (part of Papua New Guinea) and Santa Isabel in the west of Solomon Islands. It consists mainly of Choiseul Island with an area of $3,106 \mathrm{~km}^{2}$, two small islands: Wagina $\left(82 \mathrm{~km}^{2}\right)$ and Rob Roy $\left(67 \mathrm{~km}^{2}\right)$, with over 300 small islets less than $1 \mathrm{~km}^{2}$ each. 95.5 per cent of Choiseul is under tribal ownership, with the remainder being alienated land. Wagina Island makes up the largest area of alienated land in Choiseul Province (Choiseul Province Ridges to Reefs Conservation plan 2010).

Lauru is a multi-cultural society. Its population is made up predominantly of indigenous Melanesians. The total population of Choiseul Province is 26,372 with an average growth rate of 2.8 per cent (National Census, 2009). Although one of the larger islands in the Solomon Archipelago, Choiseul is considered to be very remote due to lack of basic infrastructure such as roads, wharfs, frequent shipping and air services, telecommunication and banking facilities. This lack of basic infrastructure has constrained economic development in the province and also hampers the delivery of basic health and education services (Choiseul Province Medium Term Development Plan 2009-2011).

Choiseul communities have limited income earning opportunities and they are heavily dependent on their natural resources for the survival and as means of generating cash income.

Over 90 per cent of households in Choiseul have subsistence gardens and over 86 per cent are engaged in subsistence capture of finfish (National Census 1999). More than 80 per cent are also involved in small scale copra production, and high value, non-perishable marine export products such as beche-de-mer (dried sea cucumber), trochus and shark fin are particularly sought after commodities. Other sources of income including logging royalties, small scale timber production, 


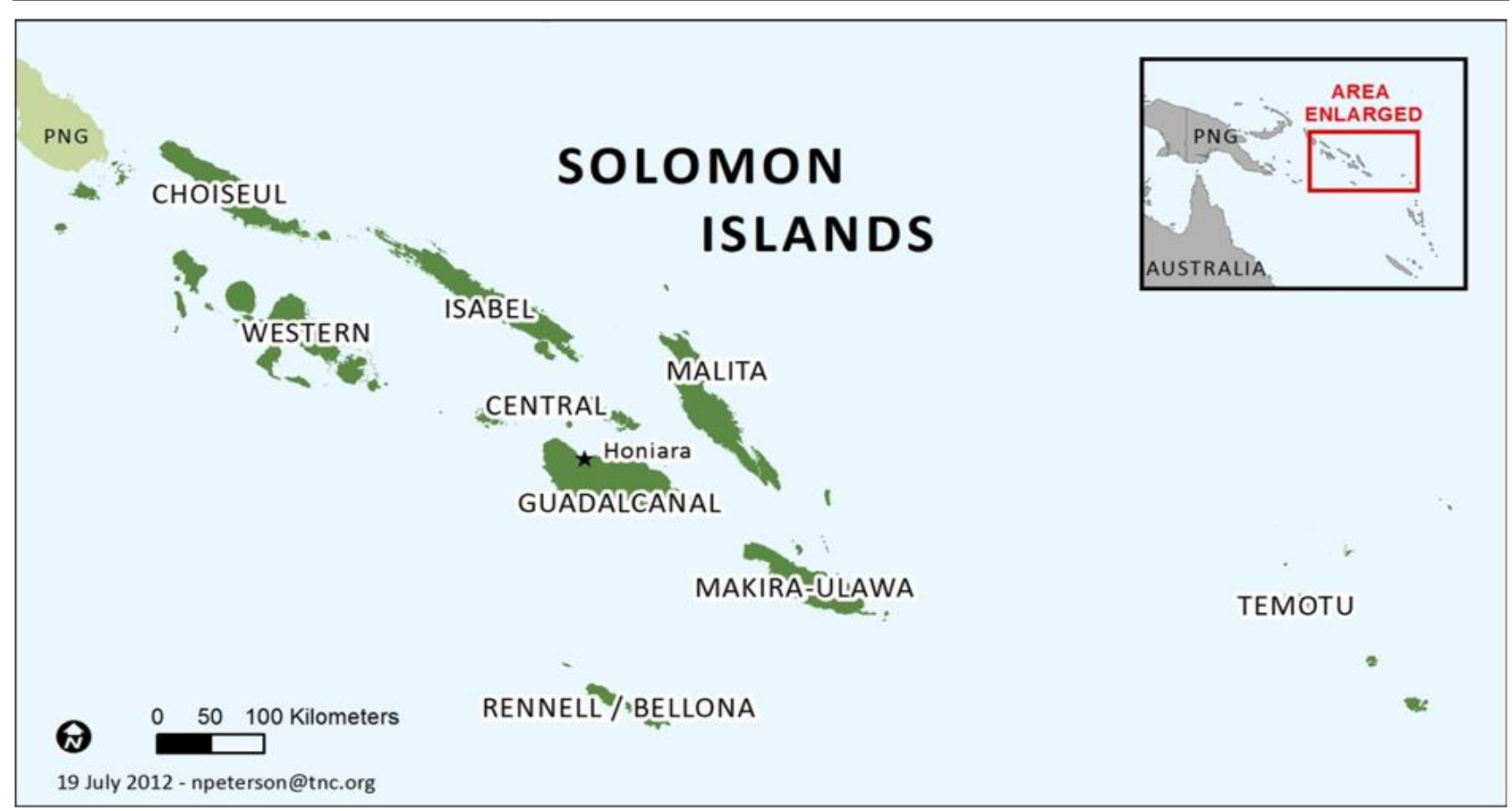

Figure 1: Provinces of Solomon Islands

remittances from family members working in urban centres in Solomon Islands and the limited sale of vegetables and finfish (Choiseul Ridges to Reefs Conservation Plan 2010)

The rural population of Lauru has a strong collective voice through the Lauru Land Conference of Tribal Community (LLCTC), an ecumenical non-governmental organization established in 1981. The LLCTC has an annual meeting that brings together all of the Chiefs and leaders of the province, and in 2006 an environmental arm was established within the LLCTC. In 2008, the LLCTC and the Choiseul Provincial Government requested support from The Nature Conservancy (TNC) for the development of a conservation plan for the land and seas of Choiseul (Lipsett-Moore et al., 2010). This request came about from an understanding that the future sustainability and prosperity of the Choiseul people are linked to the province's natural ecosystems. The development of a Choiseul conservation plan that takes biodiversity, threats to that biodiversity and opportunities for benefits from nature into account was seen as an important asset to enable the Lauru people to make wise and informed choices about their future. This is especially urgent given the pressures from logging and increased exploration by mining interests.

In its simplest form, developing a conservation plan involves comparing the distribution of biodiversity with the distribution of protected areas and finding where species and ecosystems are left unprotected or underprotected. To address these problems in a systematic way, the concept of ecological representation was developed. This refers to the need for protected areas to represent, or sample, the full variety of biodiversity of different biological realms (freshwater, marine and terrestrial through all the ecoregions) and biological scales (ecosystems, species and within-species variation) (Game et al., 2011). Many island ecosystem components provide vital goods and services, such as protection against extreme weather events, while also providing habitat for marine animals and reef fish. Thus the conservation of island biodiversity represents a costeffective and practical way for islands to ensure sustainability and adapt to threats such as climate change.

However, as with any plan and strategy, the challenge is in implementation. From the commitment to a Lauru Protected Area Network (Lauru PAN), LLCTC then needed to lead a process of demonstration, guidance and build confidence and momentum towards implementing the plan. This paper describes how the LLCTC has been successful in establishing a series of conservation areas based on the province-wide conservation plan. It focuses on identifying the challenges involved in this process and how they were overcome.

\section{METHODOLOGY}

The conservation work happening in Choiseul Province is supported by an array of partners, including The Lauru Land Conference of Tribal Community (LLCTC), Choiseul Provincial Government and The Nature Conservancy. LLCTC is the key convener and facilitator of work on the ground and is linked strongly to communities through its existing network around the 


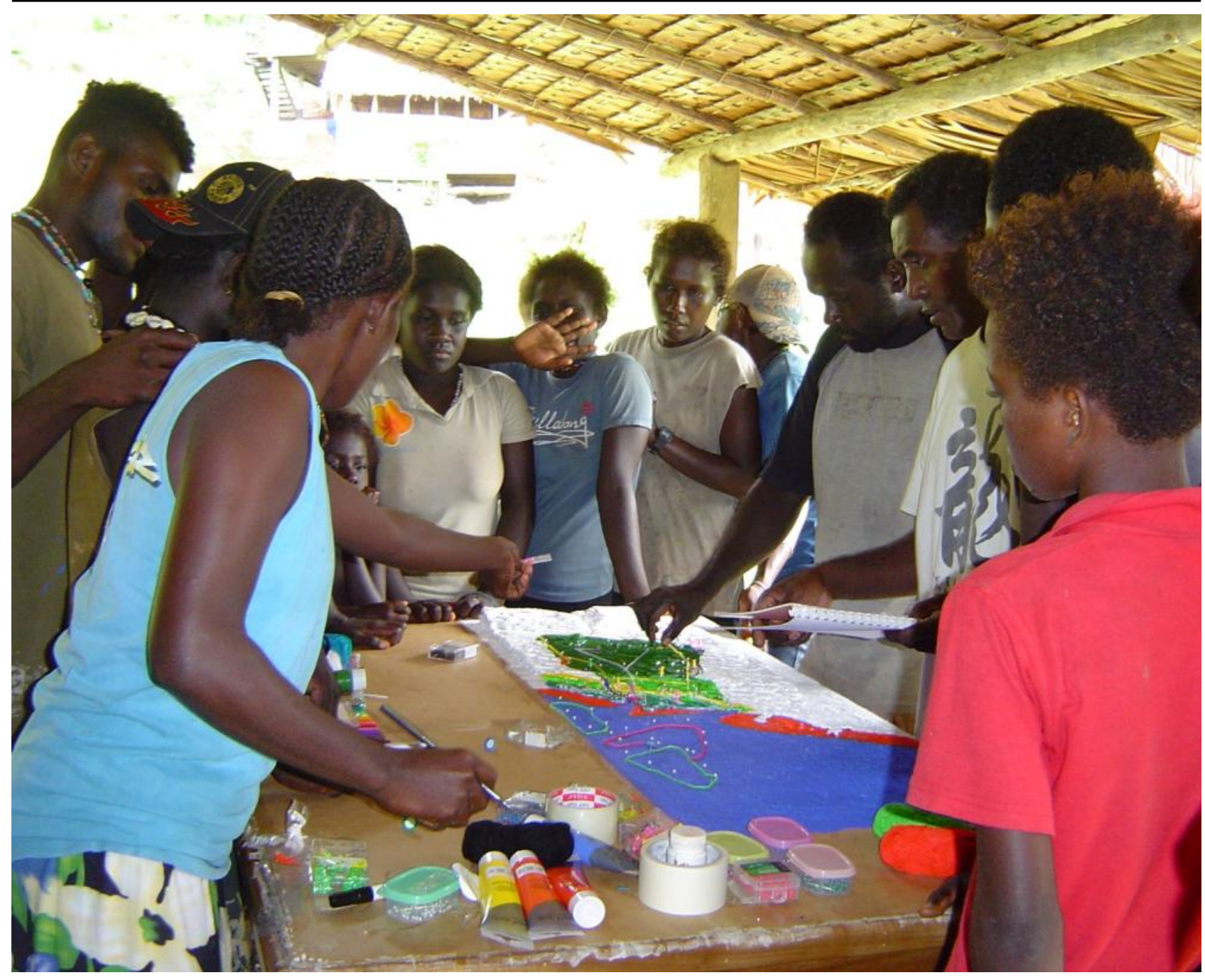

Community participation in protected area planning. LLCTC uses innovative community engagement and mapping tools, such as participatory 3D modeling, first used in Chivoko village in 2008 @ Jimmy Kereseka LLCTC

province. The LLCTC plays a role in resolving tribal disputes and disagreements. The Provincial Government supports conservation efforts by recognizing and endorsing the work at the government level; The Nature Conservancy provides additional financial and technical support to the overall programme in Choiseul Province.

Once a tribe or community becomes interested in conserving their reef or forest, they submit a request for protected area assistance to the LLCTC environment office signed by the chief and elders of a particular tribe after consulting their tribal community. Before these leaders approach the LLCTC about establishing a protected area, a full community meeting is held to ensure consensus is reached and there are no unresolved conflicts over land ownership in the proposed area. A community or tribe becomes part of the network through a clear process of engagement.

Because the LLCTC environmental office receives multiple requests, the LLCTC environment officer makes initial decisions about which community to engage with first, guided by the Choiseul Ridges to Reefs Conservation plan (Lipsett-Moore et al., 2010). Support to the community or tribe is prioritized according to extent to which their lands and seas might potentially contribute to the representative protection of Choiseul biodiversity, and also to the perceived level of the tribes' commitment.

The LLCTC officer will then manage expectations through a series of education and awareness events, initial consultations and confirmations. A key role of the LLCTC environment officer is to make sure that the interest comes from the whole tribe or community rather than from only a few representatives. This is to avoid misunderstanding between the members of the tribe with regards to the project, and to avoid marginalizing community member's voices. For example, in Zinoa community, after the initial engagement it became apparent that certain members of the community were at odds with the proposed conservation measures. In response, the LLCTC provided a full orientation and explanation of the conservation work. 


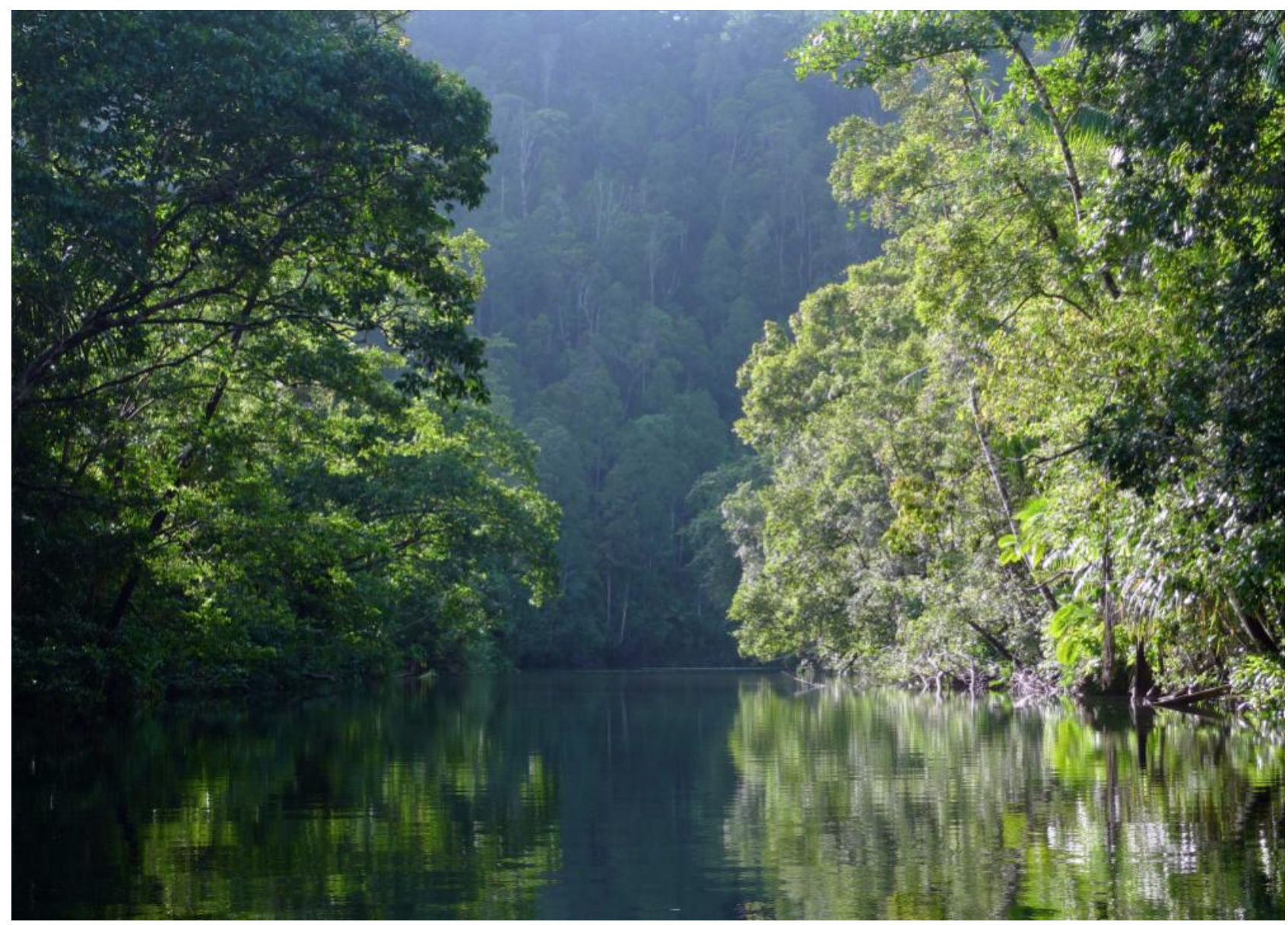

Guere Conservation Area, Choiseul. The Ridges to Reefs Conservation Plan ensures coastal and terrestrial areas are included in the Lauru PAN, such as Guere Community Conserved Area in Boe Boe community, South Choiseul @ James Hardcastle, IUCN

The next step is to introduce and explain process, tools and the Lauru Protected Area Network concept. Part of the consultation requires education regarding the importance of conservation and what type of regulations may be considered, and some of the implications. This is to give a clear understanding on the scope of the work for all partners. This is accomplished with full community involvement so they understand the realities of the project.

Next, areas that might be protected or managed are explored, again with full community involvement. The tribal community is advised of the conservation options for the area they choose to conserve, including whether to expand or change the position of the site depending on such factors as biodiversity, habitat or community history. Once an area is agreed upon, Global Positioning System (GPS) coordinates are used to demarcate the boundary of the area to be conserved. This is then synchronized with a master map maintained by the LLCTC Environment Office, with the final boundaries to become part of the Lauru PAN.

The tribal community forms a committee to oversee and manage the area to be conserved. This committee will have management authority of the area and also serve as point of contact for partners. The final step is to develop a management plan for the conservation area and produce a map of the area and update the map of the Provincial-wide network of protected areas.

Over time the established sites are monitored to track changes and trends in fish and invertebrate populations, and the health of the coral reefs or other habitats being protected. Interested community members are trained in community-based monitoring. The communities monitor the areas they conserve with the support from partners. In this way the community has a sense of ownership and greater responsibility for the management of their area and at the same time keep updated on the status of the resources in their protected area.

This initiative is coordinated with the overall conservation goals of the Solomon Islands Locally Managed Marine Areas network (SILMMA) and the Convention on Biological Diversity Programme of Work on Protected Areas (PoWPA) of Solomon Islands. LLCTC is a member of the SILMMA network that benefits from information and educational resources that can be used by the tribes and community for resource management and understanding species life histories. 


\section{RESULTS}

At the LLCTC annual general meeting in 2009, more than one hundred chiefs from around Choiseul Province made a commitment to have at least one marine and one terrestrial protected area in each ward of the province by 2013. This statement by the chiefs is a positive step in the advancement of the Lauru PAN.

The process described above is how the Lauru PAN has been advanced over the past years. The number of protected areas increased from the eight shown in figure 2 for 2008 to 15 as of June 2012 (mapping of these sites is currently in progress). The LLCTC and Environment Office receive regular letters of expression of interest from further tribal communities who are interested in setting up conservation areas. The word of mouth and continuous education and awareness on the importance of conservation, protected areas and resource management fuels this initiative.

There is continuous engagement with the established sites through monthly visits and consultation, and exchange between the established management committees. The Chivoko community themselves made an informative video ${ }^{1}$ to share with other communities, outlining the successes and challenges in protecting their forests and their reefs. This has been extremely useful as a resource for LLCTC to share in community meetings across Lauru.

LLCTC formed an environment and conservation committee in 2007, which includes representatives from the Provincial Government, The Nature Conservancy and a representative from each of the tribal communities involved in conservation. The main task of the committee is to oversee and endorse the management and operation of the Lauru PAN. The committee meets twice a year to oversee progress and endorse new sites into the Lauru PAN.

For more than five years the LMMAs have included permanent closure as a management approach. However due to the dramatic increase of their resources in the areas they manage, several communities altered their decisions and harvested resources within certain periods of time. They harvest mainly trochus shells to raise money for community projects including the church and school. In the case of Redman Island Tribal Community, in 2011 the management committee allowed the community to harvest the resources for only about three hours. Within the three hours the women and youth harvested trochus shells and clamshells for the first time since they protected the area, with proceeds from the harvest benefiting church fundraising. In the Moli

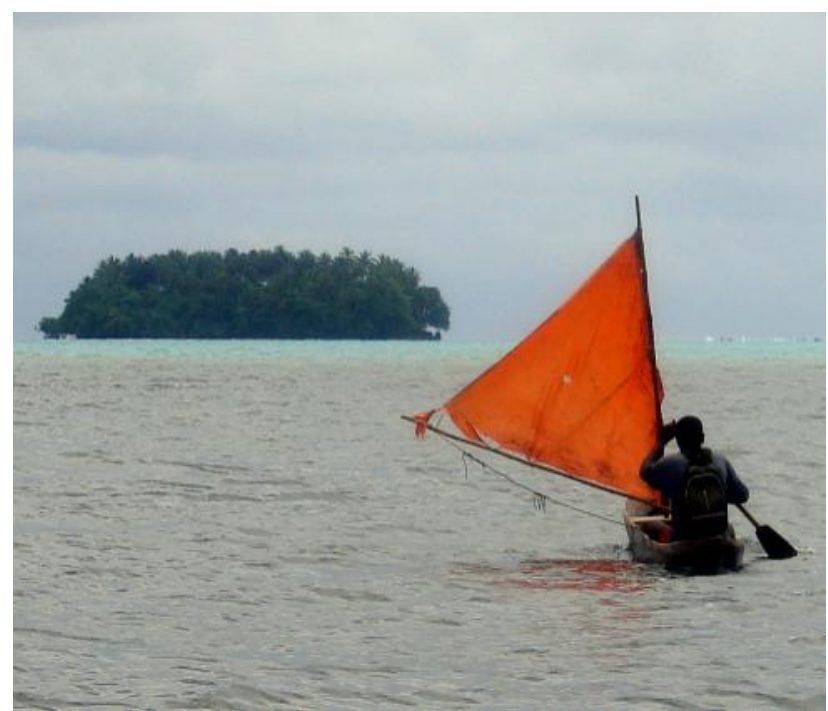

Protected Island, Choiseul. Many LMMA areas include nearshore islands (C) James Hardcastle, IUCN

community, members harvested trochus shells in the conservation area in early 2011 to go towards the students' school fees. The communities were overwhelmed by the amount of resources and the monetary value they got from harvesting the resources in these areas. Such practical examples strongly influence communities, and persuade them that there can also be monetary benefits to conservation (Read et al., 2010).

\section{CHALLENGES AND SOLUTIONS}

Disagreement over ownership of potential LMMA lands and seas: Disagreement over land ownership extending to the marine environment is a common issue in Choiseul Province. Whenever there is an incident, LLCTC deals with this according to the culture and traditional process of Lauru. The secretary of LLCTC deals directly with the tribes involved. For example, in the Rabakela conservation area two tribes have disagreements over land which affects the coastal conservation area. This case is being dealt with by LLCTC according to the tradition and culture of Choiseul, but the resolution process is time-consuming. Therefore, once we find out that there are land disputes within the community during our early engagement process, we do not progress with the engagement process but allow them to sort the issue. In the case where we have already engaged with the community before there is a dispute over land ownership, the LLCTC deals directly with the parties involved.

Disagreement within communities about conservation actions: Communities do not always agree and this can hinder the development of a plan. When communities are divided, the LLCTC does not become involved directly but helps the process by providing advice and talking with the different parties 


\section{Choiseul Province Protected Areas}

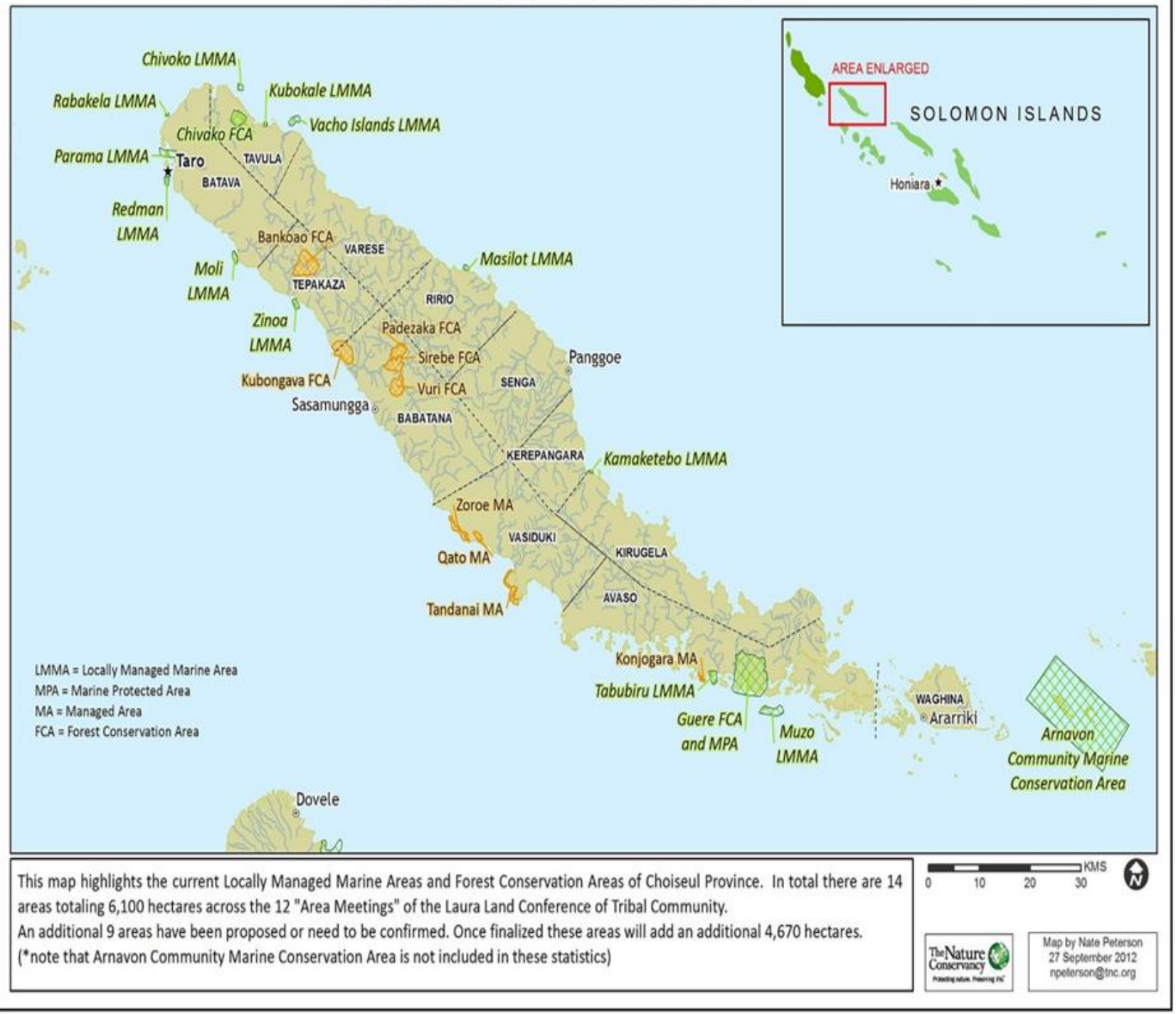

Figure 2: Locally Managed Marine Area (LMMA) under the Lauru PA Network

involved. The community is encouraged to solve the problem internally. In most cases it is easier to deal with community disagreements than with tribal disagreements.

\section{Limited capacity for community management:}

Although a management committee might be set up to oversee the overall management of the conservation area and serve as point of contact for partners who worked with them, there is no guarantee the committee has the needed skills (Filardi \& Pikacha, 2007). As part of the SILMMA network, LLCTC is able to draw upon many resources to support orientation and training for newly established committees. Also, the number of existing management committees provides a great opportunity for peer-peer exchange and learning. Furthermore, the annual meeting of the LLCTC provides a good opportunity for side-events and special sessions. Funding for management activities is generally not a major issue - aside from monitoring, most management actions become a routine part of daily activities. As such, while there is a cost, in terms of time and effort, the financial needs are minimal.

Resource monitoring: The management committees coordinate community members to help monitor the overall status of the protected area and the key resources and indicators important to the community. Training is provided by LLCTC and TNC. This component is very important for the community since it provides feedback to the customary owners on the status of their resources and provides them with a strong sense of ownership. However, LLCTC also provides external scientific biological monitoring in collaboration with The Nature Conservancy and the Choiseul Provincial Government through the fisheries division, every three to four years. 
High community expectations that may not be met: There are always monetary expectations from communities in relation to projects (Read et al., 2010). LLCTC attempts to manage these expectations by frankly informing the community of what can be achieved, and what is outside the collaborative scope of work. LLCTC make it clear from the start, and only when all are in agreement will the conservation work begin.

Deciding where to conserve: The community decides on the site they would like to conserve at the local level and LLCTC advises based on size and site, guided by the Choiseul provincial conservation plan to prioritize which community to respond to first where several requests are received at any given time. This helps LLCTC to advance the Lauru PAN according to the plan, yet also meet community resource conservation needs (Game et al., 2011).

Sustainability of the Lauru PAN after NGOs departs: This is one of the challenges that really needs to be addressed for the future of the on-the-ground work. Financial sustainability is a big concern for the LPAN. LLCTC anticipate this by building the capacity of the Environment Office to be able to oversee the project into the future. The Choiseul Provincial Government has also made a commitment to support the Lauru PAN financially through development planning and budgetary processes. At the same time LLCTC advocate and support a community-based management approaches. With all the sites LLCTC encourages the community to take the lead in managing their affairs.

Compatible livelihoods may be difficult to provide: Where feasible, LLCTC aim to support livelihoods of communities who conserve their areas, especially where there is a clear opportunity cost incurred through conservation. LLCTC are exploring options to integrate ecotourism with conservation through support to the Parama Island, Zinoa and Chivoko conservation areas to build eco-lodges to collect some income from accommodation. Additionally, Chivoko community is being supported by LLCTC and partners to develop an ecotimber operation as an alternative to industrial logging.

\section{DISCUSSION}

If the process outlined above is followed, and the local communities overcome the challenges, community-based management of local ecosystems can succeed (Keppel et al 2012). In this paper we detailed the way a conservation plan can successfully turn into conservation action on the ground and record rapid recovery of valuable marine resources following effective community-based management efforts. This is consistent with empirical cases studies from Papua New Guinea that show that community-based conservation will result in the rapid recovery of resources if management regulations are adequately enforced (e.g. Cinner et al., 2006: Hamilton et al., 2011). The key to this approach and turning the Choiseul Conservation Plan into action is the strong traditional and cultural ties to the LLCTC as an indigenous organization that belongs to the people of Lauru, which combines its traditional cultures with scientific approaches to planning and resource management.

The LLCTC is inundated with requests for help in setting up conservation areas, evidence of the success of this idea, but also an indicator that demand outstrips the capacity of LLCTC to respond in a timely manner. Initially there was no legal framework guiding the Lauru PAN since its establishment; however, communities rely very much on the traditional law and practice of dealing with unwanted action and attitudes. Based on the success in the increasing number of sites, the Choiseul Provincial Government took a leading role in developing the Choiseul Province Fishery and Marine Environment ordinance in 2011. This ordinance, now ratified in parliament, will legally bind the work that the community are involved in and further support the traditional laws that are practiced. There is a continuous positive and strong support from the Provincial Government through the fisheries division in support of the partnership effort on the ground.

The tribes and communities who have worked with LLCTC and partners for some time really understand that what they are doing with resource management is tied to long term food security for sustainable livelihoods. This understanding develops over time with continuous education and awareness. However, some tribes and communities expect conservation to provide money immediately, a result of past experience with logging royalties. This thinking will fade provided there is sufficient education and awareness building by local partners. Communities will slowly understand that monetary benefit is not the only benefit.

Generally communities do take the leading role in looking after the area from management to enforcement. Partners provide mainly technical and targeted financial support to communities. There is no expense associated with enforcement activity carried out by Lauru PAN Communities; it is perceived as common business to look after the conservation area at the community level. The integration of ecotourism and conservation will 


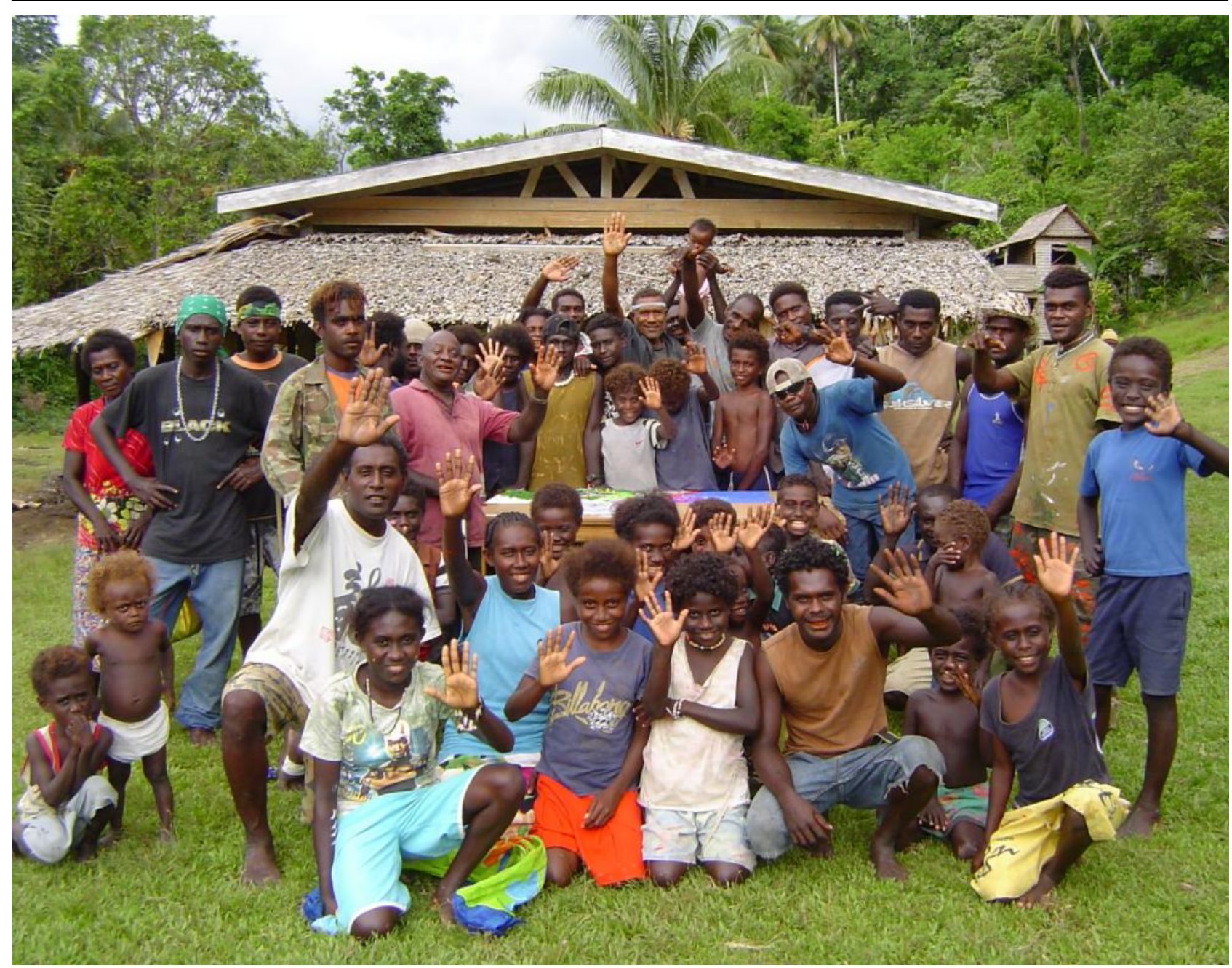

Chivoko Establish Their Locally-Managed Marine Area. Community members in Lauru freely engage in conservation activities of their own volition and motivation @ Jimmy Kereseka LLCTC

potentially support livelihoods in tandem with biodiversity conservation. The Lauru PAN is not just about conservation. The network is integrating sustainable livelihood options and social development for the communities as a benefit to conserving their marine and terrestrial environments. Communities may have many perceptions on conservation areas, but the bottom line always ties to resource management, food security and human sustainability.

There have also been failures that need attention from the conservation community. For instance, LLCTC has not been able to consistently engage several communities over time, due to constraints on human capacity at LLCTC, which employs only a small core team of staff. There is a need to continuously engage communities with other environmental activities apart from resource management, such as solid waste management, and more on climate change adaptation in conservation areas. There is a need to integrate other projects in the sites that where LLCTC works, including livelihood projects and sanitation. This is essential because when LLCTC does not access a community for a long period of time, the feedback is often negative as the community feels deserted and abandoned. We need to then re-invest more time to win back support and trust.

Furthermore, at many sites, the management committee doesn't always play an active role in the management of the conservation areas; they still rely heavily on direction from the LLCTC, and even external partners such as The Nature Conservancy, rather than leading their own planning with targeted and needs-based LLCTC support. Management will never be self-sustaining until the communities no longer require external assistance. This understanding needs strengthening as this is the anticipated way forward for the sites under the Lauru PAN.

Additionally, there is a need to develop more consistent management plans for each site, particularly recently established conservation areas. Several sites haven't started drafting their management plans and the LLCTC lacks capacity to develop plans for each community. Without management plans, there is no accountable oversight and clear representation of regulations for 
resources harvested or harvesting protocols. Management plans do not need to be in any specific format, but certain principles need to be defined and agreed upon by the whole community.

\section{CONCLUSION}

The implementation of the Lauru PAN is a long-term process, and initial progress will only translate into longer-term success if momentum can be maintained. This will be achieved if LLCTC continues to be focused on delivering clear and transparent services to communities, who are the real initiators and owners of the PA network. To date, the steady increase of sites within the Lauru PAN, the initial success and returns from enclosed and no-take zones, the results of initial biological monitoring, and the endorsement and support from all stakeholders, including Government, all suggest that the Lauru PAN is being implemented successfully. The strongest message is word of mouth on the benefits of a locally managed conservation area, passed from one community to another which triggers interest and enthusiasm to start a similar conservation area for a community.

The Lauru PAN is also a blueprint for other provinces and communities in Solomon Islands, and LLCTC and the Provincial Government are working to ensure Solomon Islands national legislation reflects and enhances the Lauru PAN experience nationally.

\section{ACKNOWLEDGEMENTS}

I would like to acknowledge all the people of Lauru and my colleagues at the Lauru Land Conference of Tribal Community - Reverend Paramount Chief Leslie Boseto, Luke Pitaköe and Michael Zazuvokara

I would especially thank The Nature Conservancy foremost Dr. Richard Hamilton, Marine Science Director for Melanesia; Willie Atu, Director of the Solomon Islands Programme; and all his staff and colleagues; but also all the friends and colleagues who have helped the LLCTC over the years, and provided advice and comments on this paper.

Thanks to James Hardcastle, now with the IUCN Global Programme on Protected Areas, for his ongoing support to the people of Choiseul.

And finally to TNC Central Science team, especially to Eddie Game, Matt Miller, Peter Kareiva for the support in writing this paper and all the donors and supporters of LLCTC who make this work happen, including Packard Foundation, MacArthur Foundation, AusAID, New Zealand AID, Swiss-RE Reinsurance.

\section{ENDNOTES}

1 The participatory video 'Conservation Story Blong Chivoko' can be viewed at: www.youtube.com/watch? $\mathrm{v}=$ zgTqt4qbLhg\&feature $=$ plcp

\section{ABOUT THE AUTHOR}

Jimmy Kereseka is the Environment Officer, Lauru Land Conference of Tribal Community (LLCTC). Until 2006 he was working as a schoolteacher in the Solomon Islands' Western Province, but then saw an advertisement for a job with The Nature Conservancy in Choiseul Province, where he was born. Much of his work is job is partnering with the LLCTC to determine how local lands are managed.

\section{REFERENCES}

Cinner, J., Marnane, M.J., McClanahan, T. R. and Almany, G. R. (2006). Periodic closures as adaptive coral reef management in the Indo-Pacific. Ecology and Society 11, 31.

Filardi C. and Pikacha P. (2007). A role for conservation concessions in Melanesia: customary land tenure and community conservation agreements in the Solomon Islands. Melanesian Geo,5, 18-23.

Game, E. T., Lipsett-Moore, G., Hamilton, R., Peterson, N., Kereseka, J., Atu, W., Watts, M. and Possingham, $\mathrm{H}$. (2011). Informed opportunism for conservation planning in the Solomon Islands. Conservation Letters, 4: 38-46.

Hamilton R.J., Potuku T. and Montambault J. (2011). Community-based conservation results in the recovery of reef fish spawning aggregations in the Coral Triangle. Biological Conservation 144(6), 1850-1858.

Keppel G., Morrison C., Watling D., Tuiwawa M. and Rounds I. A. (2012). Conservation in tropical Pacific Island countries: why most current approaches are failing. Conservation Letters, 0, 1-10

Lipsett-Moore, G., Hamilton, R., Peterson, N. Game, E., Atu, W., Kereseka, J., Pita, J., Ramohia, P. and Siota, C. (2010). Ridges to Reefs Conservation Plan for Choiseul Province, Solomon Islands. TNC Pacific Islands Countries Report No. 2/10. $53 \mathrm{pp}$.

Read J. L., Argument D. and Moseby K. E. (2010). Initial conservation outcomes of the Tetepare Island Protected Area. Pacific Conservation Biology,16, 173-180 


\section{RESUMEN}

Los pueblos y grupos indígenas de la provincia de Choiseul, o Lauru como se le conoce localmente, en las Islas Salomón, conservan un fuerte dominio consuetudinario de sus tierras y mares, y mantienen muchas costumbres relacionadas con el uso de sus recursos naturales. La población rural de Lauru también se expresa con voz firme a través de la Conferencia sobre la tierra de las comunidades tribales de Lauru (LLCTC). Las actividades de la Oficina de Medio Ambiente de la LLCTC desembocaron en 2008 en la creación de ocho áreas marinas localmente gestionadas (LMMA), y la recomendación oral sobre el valor de estas LMMA generó numerosas peticiones de la comunidad a la LLCTC solicitando asistencia para el establecimiento de áreas protegidas adicionales. En 2009, se desarrolló un plan de conservación basado en la gestión participativa para todo Lauru, que llevó a un compromiso político entre la LLCTC y el Gobierno para establecer una Red de Áreas Protegidas en la provincia de Lauro, el primero de su tipo en la Melanesia. Para 2012, se habían establecido 15 LMMA y varias áreas terrestres conservadas por la comunidad. En este documento se describe el proceso de participación comunitaria que la oficina de Medio Ambiente de la LLCTC utiliza para establecer áreas protegidas y algunos de los malentendidos que con más frecuencia es necesario abordar. También describe cómo el proceso de implementación impulsado por los propios interesados se nutre del Plan de Conservación desde las Cordilleras hasta los Arrecifes de Choiseul que se desarrolló con base en el mejor conocimiento científico y local disponible.

\section{RÉSUMÉ}

La population autochtone et les clans de la province de Choiseul, également appelée Lauru au niveau local, de l'archipel des îles Salomon, conserve un solide droit de propriété coutumière sur leurs terres et les mers, et perpétue de nombreuses coutumes liées à l'utilisation des ressources naturelles. La population rurale de Lauru exerce également une autorité collective considérable par le biais de la Lauru Land Conference of Tribal Community (LLCTC). Les activités du bureau de l'environnement du LLCTC ont abouti en 2008 à la création de huit Aires Marines localement gérées (LMMA), et le bouche à oreille sur la qualité des ces LMMA a suscité de nombreuses demandes d'assistance auprès du LLCTC afin que soient créées des zones protégées supplémentaires. En 2009, un plan de conservation, dirigé par les parties prenantes pour l'ensemble de Lauru a été mis sur pied, et suscité l'engagement politique du LLCTC et du gouvernement afin d'établir un Réseau de zones protégées à l'échelle de la province de Lauru, ce qui constitue le premier engagement de ce type en Mélanésie. Dès 2012, 15 LMMA et plusieurs aires territoriales sous protection de la communauté étaient déjà instituées. Le présent document décrit le processus d'engagement des communautés que le bureau Environnemental met en œuvre quand il établit des zones protégées, ainsi que certains des malentendus les plus courants qui doivent souvent être traités. Le document montre également comment le processus de mise en ouvre dirigé par les parties prenantes est nourri par le Choiseul Ridges to Reefs Conservation Plan, qui a bénéficié des meilleurs acquis disponibles dans les domaines des savoirs scientifiques et locaux. 